\title{
Study the Effect of Using Different Bearing Types on the Vibration of Evaporative Cooler
}

\author{
Shaker S. Hassan Ahmed Adnan Shandookh Omar Alaa Ihsan \\ Mechanical Engineering Department, University of Technology, Baghdad, IRAQ \\ Shaker_Sakran1952_1@yahoo.com Abomrem2004@gmail.com omar_msc851@yahoo.com
}

Received: 08-Oct.-2018 Revised:04-Nov.-2018 Accepted: 14-Nov.-2018

http://doi.org/10.29194/NJES.21040532

\begin{abstract}
An investigation of performance response of two types of bearings such as Cylindrical Roller Bearing and bush bearing on evaporative cooler driven by DC motor of 1500 r.p.m, through studying many parameters like vibration response, temperature raise, humidity, sound level and total performance. high quality $3 \mathrm{D}$ positions $\mathrm{X}, \mathrm{Y}$ and $\mathrm{Z}$, vibration sensors type (ADXL335 accelerometers) with Arduino mega 2560 that interfaced with Lab-View program were used to measure changes in vibration amplitude and frequency. Two temperature sensors of type (LM35) were used to investigate the temperature raise in the bearings also with Arduino mega 2560 that interfaced with Lab-View program. For humidity a sensor of type DHT22 was used, also, a portable device was used to measure electricity consumption, rotary speed and sound level in the bearings of evaporative cooler. By replacing bearings all the parameters above wear measured then a comparison between them were made to find the best performance and operation of these bearings. The obtained results from the experimental work have clarified and explained by tables and figures. It has been found that the vibration of evaporative cooler in $\mathrm{X}, \mathrm{Y}$ and $\mathrm{Z}$ directions increased by using two cylindrical roller bearings than using two of bush bearings. The temperature of cylindrical roller bearings increased When running the evaporative cooler more than bush bearings. the noise of Evaporative Cooler by using both types of Bearings was almost same but with a little Reduce by using cylindrical roller Bearings. Which means the Evaporative Cooler has better Performance by using bush bearings than using cylindrical roller bearings.
\end{abstract}

Keywords: Bearings, Evaporative Cooler, Sensors

\section{Introduction}

Evaporative Cooler is a machine used to reduce the temperature and raise the humidity of air by utilization latent heat of evaporation, changing liquid water to water vapor. In this action, the energy does not change in the air. cozy dry air is changed to cold moist air. The outside air is used to evaporate water, like any other machine, it consists of many parts, and bearing is one of the most important parts in it.

Bearings are tribological ingredients which carry loads while in contact with part and move it to another part relatively. The bearings movement might be rotating, or it might be sliding. There are essentially two different bearings types: roller element bearings and plain bearings. Plain bearings (also referred to as journal bearings or bushings) are used to lower friction in linear or rotary applications. It operates through a sliding action. Bushings are made from an assortment of materials and usually it would be self-lubricating to give smooth operation and greater strength, it is a cylindrical with straight inner and outer diameter. Rolling-element bearings utilize balls, cylindrical or tapered rollers. These rolling elements are contained within a ring of bearing "races", they aperient motion with a little sliding resistance. Cylindrical roller Bearing is one of the most common bearing types, can carry radial loads SITRC [1].

\section{Vibration Analysis}

Commercially a Fast Fourier Transformation (FFT) analyzers tool is an equivalent tool for spectrum interpretation. They provide constant bandwidth and they also provide a high resolution in any frequency range of advantage Dr. S. J. Lacey [2] FFT analyzers may provide diagnostic tools, like synchronous time averaging Eshleman, R. L. [3]. FFT was used as mentioned in this study. A tabulation of machine frequencies is necessary to appropriate it with frequencies obvious in the results. Vibration Troubleshooting Chart has been used to estimate of other parts frequencies of evaporative cooler as shown in table-1.

Table 1: A Vibration Troubleshooting Chart

\begin{tabular}{|c|c|c|c|}
\hline $\begin{array}{c}\text { Nature of } \\
\text { source }\end{array}$ & $\begin{array}{c}\text { Frequency of } \\
\text { dominant } \\
\text { vibration, } \\
\mathrm{Hz}=\mathrm{rpm} / 60\end{array}$ & Direction & Remarks \\
\hline $\begin{array}{c}\text { Rotating } \\
\text { members out of } \\
\text { balance }\end{array}$ & $\begin{array}{c}\text { Usually } 1 * \\
\mathrm{rpm} \\
\text { Often } 2 * \text { rpm } \\
\text { Sometimes } 3 \\
\text { and } 4 * \text { rpm }\end{array}$ & $\begin{array}{c}\text { Axial and } \\
\text { Radial }\end{array}$ & A common fault \\
\hline $\begin{array}{c}\text { Journal } \\
\text { bearings loose } \\
\text { in housing }\end{array}$ & $\begin{array}{c}\text { Sub harmonics } \\
\text { of shaft rpm, } \\
\text { exactly } 1 / 2 \text { or } \\
1 / 3 * \text { rpm }\end{array}$ & radial & $\begin{array}{c}\text { Looseness may only } \\
\text { develop at operating } \\
\text { speed } \\
\text { and temperature (e.g., } \\
\text { turbo machines) }\end{array}$ \\
\hline
\end{tabular}




\begin{tabular}{|c|c|c|c|}
\hline $\begin{array}{l}\text { Oil-film whirl } \\
\text { or whip in } \\
\text { journal } \\
\text { bearings }\end{array}$ & $\begin{array}{l}\text { Slightly less } \\
\text { than half shaft } \\
\text { speed } \\
\text { (42 to } 48 \\
\text { percent) } \\
\end{array}$ & radial & $\begin{array}{l}\text { Applicable to high- } \\
\text { speed (e.g., turbo) } \\
\text { machines }\end{array}$ \\
\hline $\begin{array}{l}\text { Damaged or } \\
\text { worn gears }\end{array}$ & $\begin{array}{l}\text { Tooth- } \\
\text { meshing } \\
\text { frequencies } \\
\text { (shaft rpm } \\
\text { *number of } \\
\text { teeth) and } \\
\text { harmonics }\end{array}$ & $\begin{array}{l}\text { Axial and } \\
\text { Radial }\end{array}$ & \begin{tabular}{|} 
Sidebands around \\
tooth-meshing \\
frequencies indicate \\
modulation (e.g., \\
eccentricity) at \\
frequency \\
corresponding to \\
sideband spacing. \\
Normally only \\
detectable with very \\
narrowband \\
Analysis and spectrum \\
analysis. \\
\end{tabular} \\
\hline $\begin{array}{l}\text { Mechanical } \\
\text { looseness }\end{array}$ & $2 * \mathrm{rpm}$ & & $\begin{array}{c}\text { Also, sub- and inter } \\
\text { harmonics, as for loose } \\
\text { journal bearings }\end{array}$ \\
\hline $\begin{array}{c}\text { Faulty belt } \\
\text { drive }\end{array}$ & $\begin{array}{c}1,2,3 \text { and } 4 \mathrm{x} \\
\text { rpm of belt }\end{array}$ & Radial & $\begin{array}{c}\text { The precise } \\
\text { problem can usually be } \\
\text { identified visually with } \\
\text { the help of a } \\
\text { stroboscope }\end{array}$ \\
\hline $\begin{array}{l}\text { Unbalanced } \\
\text { reciprocating } \\
\text { forces and } \\
\text { couples }\end{array}$ & $\begin{array}{l}\text { 1x rpm and/or } \\
\text { multiples for } \\
\text { higher-order } \\
\text { unbalance }\end{array}$ & radial & \\
\hline $\begin{array}{l}\text { Electrically } \\
\text { induced }\end{array}$ & $\begin{array}{c}1 * \text { rpm or } 2 \\
\text { times line } \\
\text { frequency }\end{array}$ & $\begin{array}{l}\text { Axial and } \\
\text { Radial }\end{array}$ & $\begin{array}{r}\text { Should disappear } \\
\text { when power turned off }\end{array}$ \\
\hline
\end{tabular}

Frequency multipliers equations have been used too to provide a theoretical estimate of healthy and defective parts frequency of Cylindrical Roller Bearing to be expected, these equations were: K. Ragulskis [4], T. A. Harris [5], H. Ohta [6] and A. Palmgren [7].

$$
\begin{aligned}
& f_{F C C F}=\frac{f_{s}}{2}\left(1-\frac{D_{R}}{D_{c}} \cos \theta\right) \\
& f_{R P O F}=\frac{N_{R}}{2} f_{s}\left(1-\frac{D_{R} \cos \theta}{D_{c}}\right) \\
& f_{R P I F}=\frac{N_{R}}{2} f_{s}\left(1+\frac{D_{R} \cos \theta}{D_{c}}\right) \\
& f_{R}=\frac{D_{c}}{2 D_{R}} f_{s}\left(1-\frac{D_{R}{ }^{2} \cos \theta^{2}}{D_{c}{ }^{2}}\right)
\end{aligned}
$$

where: $f_{F C C F}$ is the fundamental cylindrical roller cage frequency, $f_{R P O F}$ is the roller pass outer raceway frequency, $\left(f_{R P I F}\right)$ the roller pass inner raceway frequency, $\left(f_{R}\right)$ the roller rotational frequency, $N_{R}$ is number of rollers $f_{S}$ is rotational frequency of shaft, $D_{R}$ is the roller diameter, $D_{c}$ is the cage diameter of the bearing and $\theta$ is the bearing contact angle.

\section{Experimental Work}

In this research an experimental comparison of vibration response, temperature raise, humidity changes and the noise level between bush bearing and cylindrical roller bearing that used in evaporative cooler, a Fast Fourier Transformation technique of vibration analysis has been used to study the effects of vibration response, amplitude and frequency for these types of bearings. The main objective of this study is to investigate the best type of bearing which will give the optimum performance and operation of the evaporative cooler, vibration analysis requires accelerometers
(Vibration sensors), data acquisition to recode and transfer data to a computer which it will requires a specialized software's for the purpose of data processing. An evaporative cooler with $25 \mathrm{~mm}$ Diameter and DC motor provide 1500 r.p.m. speed as shown in figure-1 were used, vibration response, amplitude and frequency, have been measured, as well as bearings temperature, sound level and electricity consumption of the evaporative cooler in two case studies, the first case by using bush bearing on the evaporative cooler, while, the second case by replace the bush bearing by cylindrical roller bearing, the replacement process is required some of mechanical works for fitness and to install the bearings in the desired place.

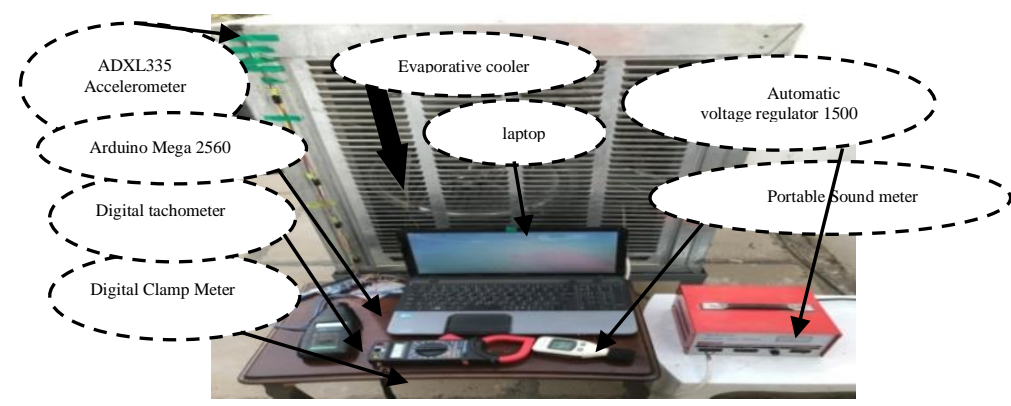

Figure 1: The Evaporative Cooler with Measuring Tools \& Devices

A structural stand made of steel was manufactured to carry the evaporative cooler with a dimension of $(90 \times 76 \times 40) \mathrm{mm}$, a layer of rubber was included with a thickness of $10 \mathrm{~mm}$ on the top surface of the stand in order to isolate the evaporative cooler as a foundation. An automatic voltage regulator of $1500 \mathrm{VA}$ was used because of bad electricity frequent arrived also, to provide stable electricity with 220 voltages to make sure of the stability of motor speed. A digital clamp meter was applied to measure the electricity consumption of the evaporative cooler in voltage unit for both bush and cylindrical roller bearings and to compare between the results of both cases as shown in fig.(1). A portable Sound level meter with measurement range of 30 130 dB and accuracy up to $\pm 1.5 \mathrm{~dB}$ was used to measure the sound level of the evaporative cooler in $\mathrm{dB}$ unit for both bush and cylindrical roller bearing also, to compare between the results of both cases as shown in Fig.(1). A three of ADXL335 3D accelerometers sensors with $330 \mathrm{mV} / \mathrm{g}$ in sensitivity and range of reading of $(0.5 \sim 1600) \mathrm{Hz}$ in the $\mathrm{X}$ and $\mathrm{Y}$ axes and $(0.5 \sim$ 550) $\mathrm{Hz}$ in $\mathrm{Z}$ axis, accelerometers were mounted on every bearing's housing as shown in Fig.(2). While, the third accelerometer was mounted on the evaporative cooler external structure as shown in Fig.(1). The y-axis of the accelerometer represents the axial direction of the shaft, while, $x$-axis of the accelerometer represents the horizontal radial direction of the shaft and finally, the z-axis of the accelerometer represents the vertical radial 
direction of the shaft M.S. Samhouri [8]. The accelerometers were connected to Arduino mega 2560 with $16 \mathrm{MHz} \mathrm{CPU}$ and the Arduino was connected to Ci7 laptop. Two of LM 35 temperature sensors were used and mounted on the bearing's housings then connected to the Arduino mega 2560. A DHT22 sensor was used and connected to the Arduino mega 2560 too. For these sensors to be worked, the computer must have a some necessary programs to be installed on it first, for a simple case it will need Arduino program installed on the computer in order to make it receive of the bearing's date of the vibrations and temperature and humidity from the Arduino to be displayed by the computer, but unfortunately, these results might needs too more complex procedures, one of these procedures is to convert the vibration results from time domain to frequency domain by using FFT (Fast Fourier Transformation) which, requires more complicated software's Harris T A [9]. To solve that it is necessarily to install a LabVIEW program on the computer and interfering the LabVIEW with the Arduino board by using (LIFA) base code on the Arduino software Alaa A. Jaber [10]. After that a block diagram for the ADXL335 accelerometer was built by LabVIEW to receive the date of vibration signals from the accelerometers and to make a calibration process on it, to transform the vibration result units from voltage to $g$ (gravity unit), then by using FFT technique to display the results on the computer in time and frequency domain form, all as shown in Fig.(3). A digital tachometer was used for the analyzing of vibrations signal by measure the r.p.m. speeds of every single rotary part in the evaporative cooler to find out the vibration sources as shown in Fig.(1). Another two LabVIEW block diagram was also used. The first one was used to receive the temperature signal from the LM 35 sensors and to display the results on the computer in time-temperature chart as shown in Fig.(4) and the other block diagram used to receive the room temperature and humidity signal from DHT22 sensor to display the results on the computer too as shown in Fig.(5).
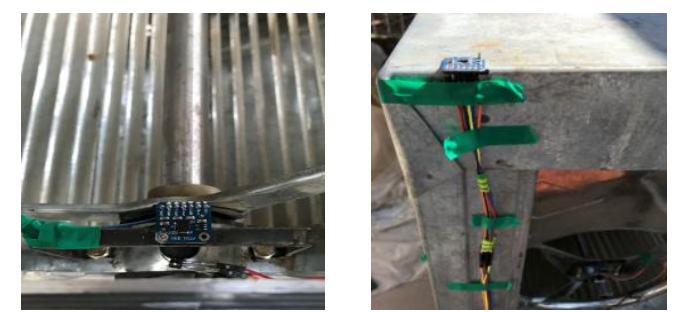

Figure 2 a \& b: Three accelerometers and LM35 Sensors mounted on different points of EC

The rotary speed of every single rotating part in the evaporative cooler at the time of measuring vibrations reading has been measured, the rotary speed of the motor shaft and the smaller pulley were $1471 \mathrm{rpm}$ and the rotary speed of the main shaft (1x), the larger pulley and the centrifugal fan speeds were $347 \mathrm{rpm}$, a V belt type used in the EC with $1475 \mathrm{~mm}$ length in both cases.

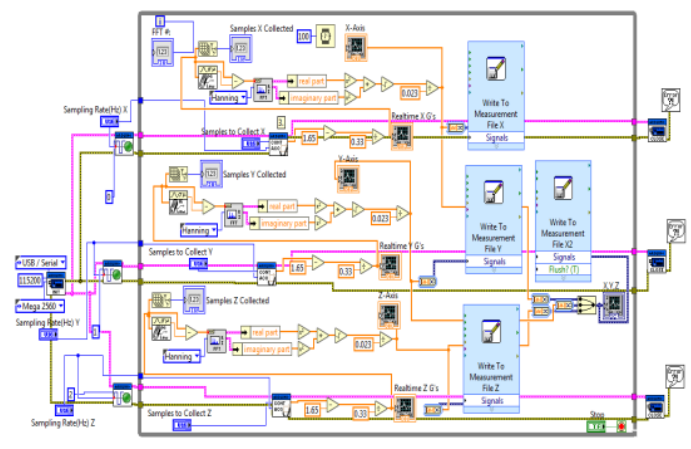

Figure 3: A Lab-View Block Diagram for one of ADXL335 Accelerometers

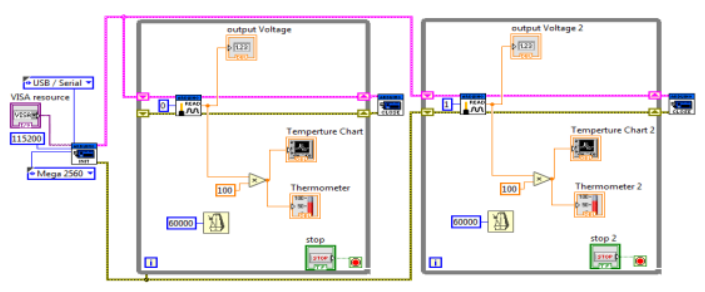

Figure 4: A LabVIEW Block Diagram for Two of LM35 Sensors

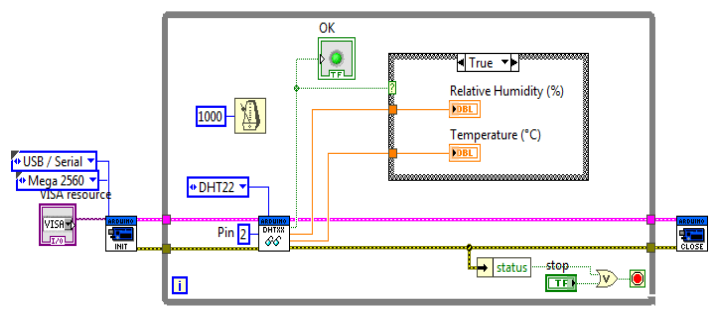

Figure 5: A LabVIEW Block Diagram for DHT22 humidity and temperature Sensor

\section{Humidity and Temperature}

Humidity and environmental temperature have been measured before take temperature readings of bush, ball, cylindrical roller bearings and tapered roller bearings to be sure that all readings will be in same environmental conditions. Humidity were $(47 \%)$ and environmental temperature were (27) degrees celsius in these for cases.

\section{Vibration Results and Discussions}

The vibration at three points on the evaporative cooler with two bushings and then with two cylindrical roller bearings respectively have been measured experimentally for $\mathrm{X}, \mathrm{Y}$ and $\mathrm{Z}$ directions, and the results is as shown in the next charts: 


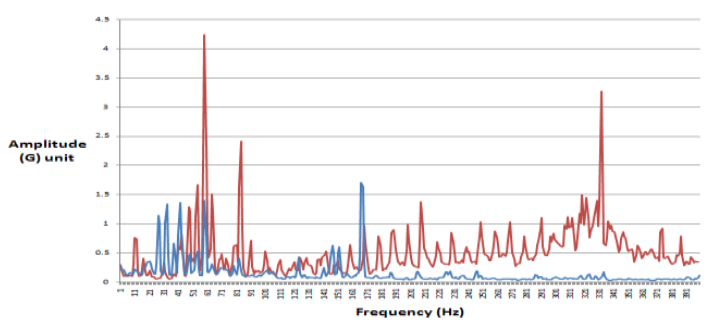

Chart 1: Figure (5): a chart for FFT/ $1^{\text {st }}$ Accelerometer / X-direction (blue curve for bushing and the red curve for cylindrical roller bearing)

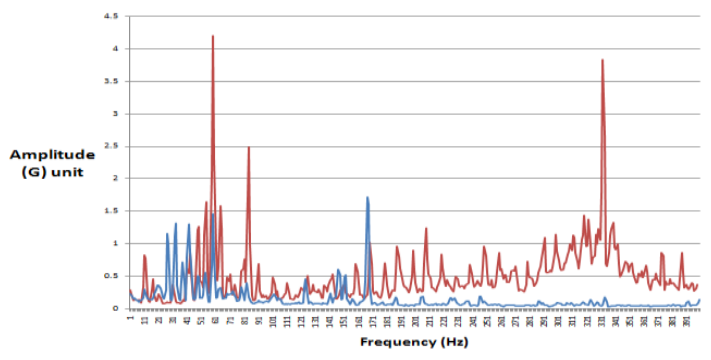

Chart 2: $F F T / 1{ }^{\text {st }}$ Accelerometer $/ Y$-direction (blue curve for bushing and the red curve for cylindrical roller bearing

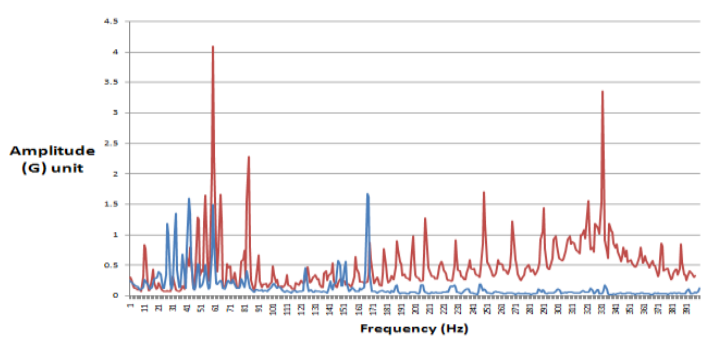

Chart 3: FFT/ $1^{\text {st } A c c e l e r o m e t e r ~ / ~ Z-d i r e c t i o n ~}$ (blue curve for bushing and the red curve for cylindrical roller bearing

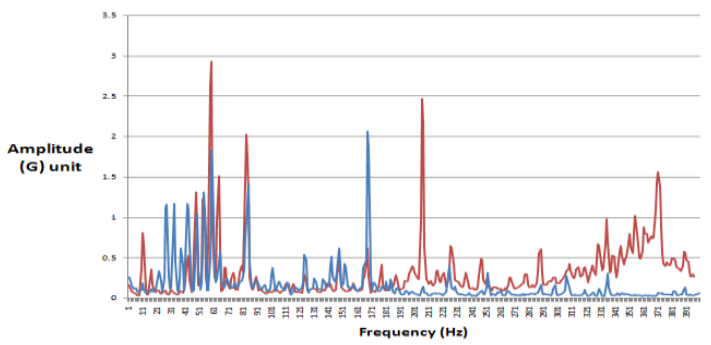

Chart 4: FFT/2 ${ }^{\text {nd }}$ Accelerometer / X-direction (blue curve for bushing and the red curve for cylindrical roller bearing)

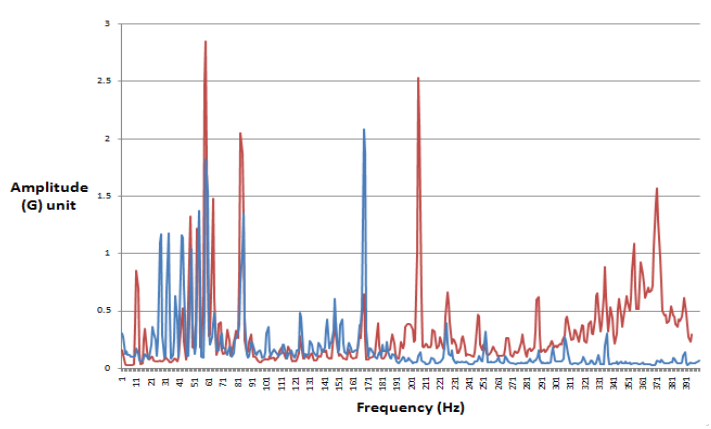

Chart 5: FFT/ $2^{\text {nd }}$ Accelerometer / Y-direction (blue curve for bushing and the red curve for cylindrical roller bearing)

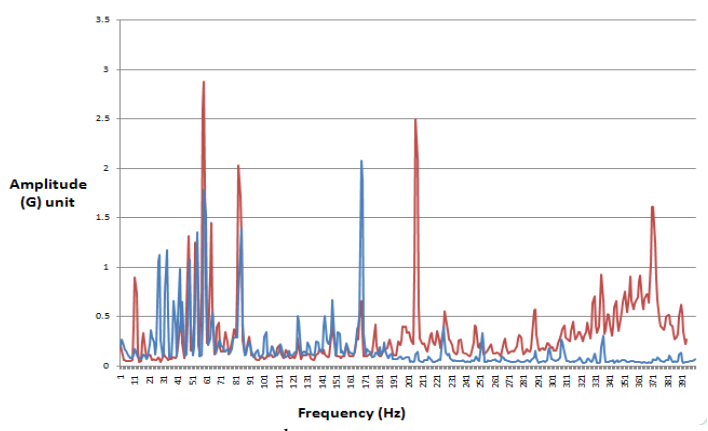

Chart 6: FFT/ $2^{\text {nd }}$ Accelerometer / Z-direction (blue curve for bushing and the red curve for cylindrical roller bearing)

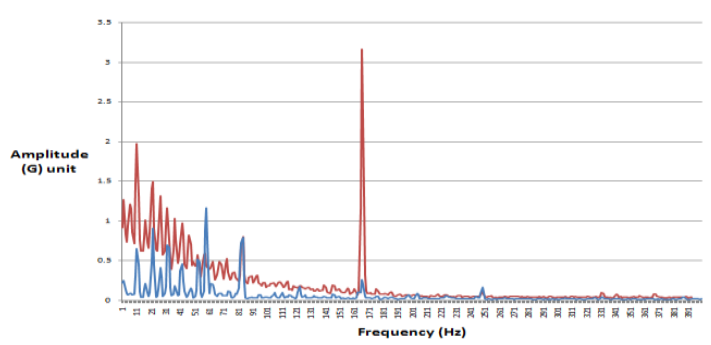

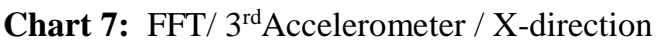
(blue curve for bushing and the red curve for cylindrical roller bearing)

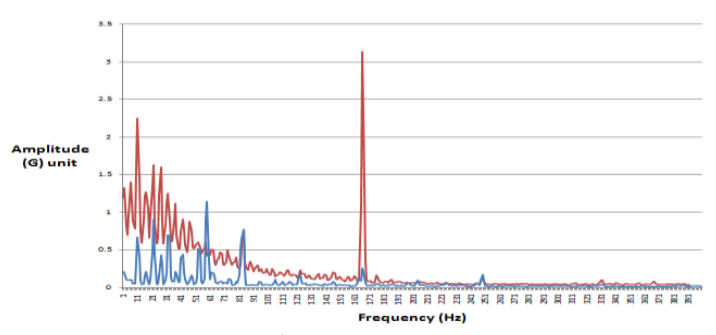

Chart 8: $\mathrm{FFT} / 3^{\text {rd }}$ Accelerometer / Y-direction (blue curve for bushing and the red curve for cylindrical roller bearing) 


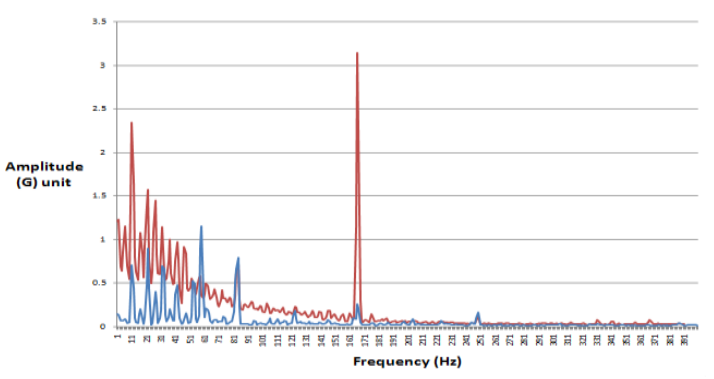

Chart 9: FFT $/ 3^{\text {rd }}$ Accelerometer / Z-direction (blue curve for bushing and the red curve for cylindrical roller bearing)

The Equations (1, 2, 3 and 4) and the table (2) have been used to provide a theoretical estimate of healthy parts frequency (and defective parts If they exist) to be expected as shown in table-2.

Table 2: Theoretical frequencies of main parts of evaporative cooler

\begin{tabular}{|c|c|}
\hline Vibration source & $\begin{array}{c}\text { Theoretical frequency } \\
(\mathrm{Hz})\end{array}$ \\
\hline $\begin{array}{c}\text { Shaft Rotational } \\
\text { Frequency }\end{array}$ & 5.783 \\
\hline large pulley & 11.566 \\
\hline small pulley & 49.033 \\
\hline $\boldsymbol{f}_{F C C F}$ & 2.493 \\
\hline$f_{R P O F}$ & 29.946 \\
\hline$f_{R P I F}$ & 40.931 \\
\hline$f_{R}$ & 20.713 \\
\hline
\end{tabular}

by matching the machine and the measured frequencies it was found out that the shaft frequency at $(5) \mathrm{Hz}$ which it represent $(1 \mathrm{X})$ where $(\mathrm{X})$ is corresponding frequency which mean shaft Frequency multiples $(\mathrm{x} \mathrm{Hz})$, the frequency of the large pulley was $(11) \mathrm{Hz}$ which it represent $(2 \mathrm{X})$, the frequency of the small pulley was $(48) \mathrm{Hz}$, the centrifugal fan frequency was $(59) \mathrm{Hz}$ at $(11.6 \mathrm{X})$, after replacing two bushings by two cylindrical roller bearing it was found a clearly Increasing of the vibration at $\mathrm{X}, \mathrm{Y}$ and $\mathrm{Z}$-directions which has been measured from the accelerometers on the two bearings and on the external structure of evaporative cooler. Table-3 show Measured frequencies of main parts of evaporative cooler and bearing periodic frequencies.

Table 3: Measured frequencies of main parts of evaporative cooler and bearing periodic frequencies

\begin{tabular}{|c|c|c|}
\hline Vibration source & $\begin{array}{c}\text { Measured } \\
\text { frequency } \\
(\mathrm{Hz})\end{array}$ & $\begin{array}{c}\text { Corresponding } \\
\text { Frequency }(\mathrm{x} \\
\mathrm{Hz})\end{array}$ \\
\hline Shaft Rotational Frequency & 5 & $1 \mathrm{X}$ \\
\hline large pulley & 11 & $2 \mathrm{X}$ \\
\hline small pulley & 48 & $9 \mathrm{X}$ \\
\hline Centrifugal fan & 59 & $11.8 \mathrm{X}$ \\
\hline $\begin{array}{c}\text { Fundamental Cylindrical } \\
\text { Roller Cage Frequency } \\
\left(f_{F C C F}\right)\end{array}$ & ------ & ----- \\
\hline
\end{tabular}

\begin{tabular}{|c|c|c|}
\hline $\begin{array}{c}\text { Roller Pass Outer Raceway } \\
\text { Frequency }\left(f_{R P O F}\right)\end{array}$ & 30 & $6 \mathrm{X}$ \\
\hline $\begin{array}{c}\text { Roller Pass Inner Raceway } \\
\text { Frequency }\left(f_{R P I F}\right)\end{array}$ & 40 & $8 \mathrm{X}$ \\
\hline $\begin{array}{c}\text { Roller Rotational Frequency } \\
\left(f_{R}\right)\end{array}$ & 21 & $4.2 \mathrm{X}$ \\
\hline
\end{tabular}

an average values of magnitude of vibration amplitudes which appeared in the spectrum (the frequency domain of FFT ) of three positions on the evaporative cooler at $\mathrm{X}, \mathrm{Y}$ and Z-directions by using two of Bush Bearings and two of cylindrical roller bearings in the evaporative cooler have been calculated by divided the sum of amplitudes magnitude on the number of spectrum amplitudes, the calculation of an average value of the vibration sources by using both, two bush bearings and two cylindrical roller bearings respectively at $\mathrm{X}, \mathrm{Y}$ and Z-directions are as shown in the Table- 4 .

Table 4: Average Value of the Vibration Sources

\begin{tabular}{|c|c|c|c|}
\hline $\begin{array}{c}\begin{array}{c}\text { Positions of the } \\
\text { three }\end{array} \\
\text { accelerometers } \\
\text { which represent } \\
\text { the three } \\
\text { different points } \\
\text { on the } \\
\text { evaporative } \\
\text { Cooler } \\
\end{array}$ & $\begin{array}{c}\text { The Direction of } \\
\text { measurement }\end{array}$ & $\begin{array}{l}\text { The average } \\
\text { magnitude of } \\
\text { vibration Sources } \\
\text { Amplitudes of the } \\
\text { evaporative } \\
\text { cooler with two } \\
\text { bush bearings } \\
\text { (G) unit }\end{array}$ & $\begin{array}{c}\text { The average } \\
\text { magnitude of } \\
\text { vibration Sources } \\
\text { amplitudes of the } \\
\text { evaporative cooler } \\
\text { with two } \\
\text { cylindrical roller } \\
\text { bearings }(\mathrm{G}) \text { unit }\end{array}$ \\
\hline \multirow{3}{*}{$\begin{array}{c}\text { The first } \\
\text { accelerometer on } \\
\text { the bearing } \\
\text { (other side of } \\
\text { pulleys) }\end{array}$} & X-dir & 0.1 & 0.50 \\
\hline & Y-direc & 38 & 0.4 \\
\hline & $\mathrm{Z}$ & 6 & 0.4957 \\
\hline \multirow{3}{*}{$\begin{array}{c}\text { The second } \\
\text { accelerometer on } \\
\text { the bearing (near } \\
\text { the pulleys) }\end{array}$} & $\mathrm{X}$-direction & 0.174468 & 0.319984 \\
\hline & Y-direction & 0.175894 & 0.319549 \\
\hline & Z-direction & 0.177302 & 0.318248 \\
\hline \multirow{3}{*}{\begin{tabular}{|c|} 
The third \\
accelerometer on \\
the External \\
structure)
\end{tabular}} & $\mathrm{X}$-direction & 0.068019 & 0.217512 \\
\hline & Y-direction & 0.068 & 0.232432 \\
\hline & Z-direction & 0.068123 & 0.217769 \\
\hline
\end{tabular}

$*(\mathrm{G})$ the unit of gravity (meter/ $\mathrm{Sec}^{2}$ )

M. Gietzelt $(2008)^{11}$.

From above charts and tables it is clearly noted that by using bushings bearing will leads to get greater increments in vibration amplitude, in all the three tested points on the evaporative cooler at the $\mathrm{X}, \mathrm{Y}$ and Z-directions rather than using the cylindrical roller bearing for the shaft, while, for centrifugal fan and the two pulleys butting together with using the cylindrical roller bearing in the evaporative cooler will leads to get a high vibration from the rollers, both inner race and outer race with high frequencies too. After comparison of the average value of the vibration sources that shown in the Table- 3 , it was found out that the vibration of the evaporative cooler by using bushings will bring a less vibration than using the cylindrical roller bearing in all direction at the bearings, A reason for the increasing of vibration level by using cylindrical roller bearing was the existence of relatively large clearance compared with bushings clearance that causes impact among rollers, inner and outer races of cylindrical roller bearing. 


\section{Bearings Temperature Results and Discussions}

The testing time was turned on the evaporative cooler for thirty minutes and by using two of LM35 temperature sensors, the temperature of two bushing was record, to get a temperature reading every minute for thirty minutes. After replacing two bushings by two of cylindrical roller bearing, a new recording for the temperatures of both cylindrical rollers bearing every minute for thirty minutes using the same LM35 temperature sensors and the next charts show the results of bushing bearings and cylindrical roller bearings temperatures:

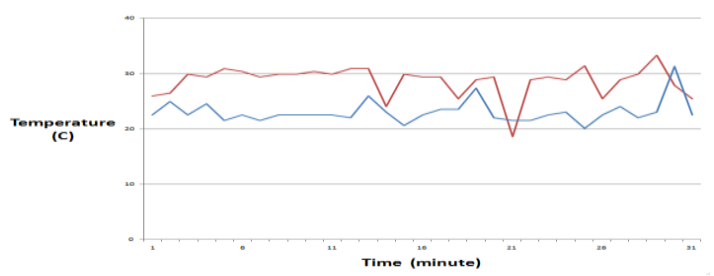

Chart (10): The Results of the $1^{\text {st }}$ Bush and cylindrical roller bearing Temperatures (the blue curve for the bushing and the red curve for the cylindrical roller bearing).

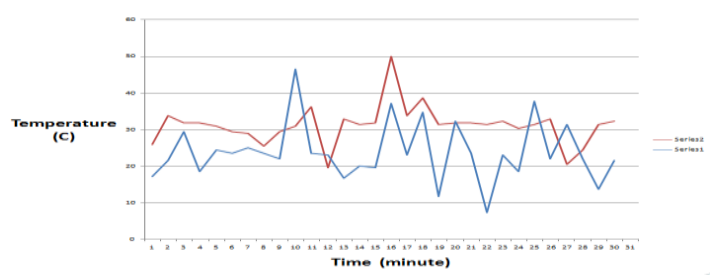

Chart (11): The Results of the $2^{\text {nd }}$ Bushing and cylindrical roller bearing temperatures (the blue curve for the bushing and the red curve for the cylindrical roller bearing).

From the above two charts the temperatures remain volatile up and down in both cases by using bushings and cylindrical roller bearing respectively have been noted and it does not keep increasing, the reason for this is the rotational motion of the moving parts in the evaporative cooler works on cooling the bearings. We noted too that the temperatures of bearings near the pulleys are greater volatility up and down than the bearings in the other side of the shaft because the pulleys and the belt is nearby it and their movements cooling the bearing. Average of 30 values of temperatures results of both LM35 sensors have been calculated in both cases as shown in table-5.

Table 5: The Average Value of the bearings temperatures of two types of bearings

\begin{tabular}{|c|c|c|}
\hline $\begin{array}{c}\text { Measured cases } \\
\text { with four Bearings } \\
\text { types used in the } \\
\text { EC }\end{array}$ & $\begin{array}{c}\text { The average of } \\
\text { bearing temperatures } / \\
1^{\text {st }} \text { LM35 sensor }\left(C^{\circ}\right)\end{array}$ & $\begin{array}{c}\text { The average of } \\
\text { bearing } \\
\text { temperature / 2 } \\
\text { LM35 sensor }\left(\mathrm{C}^{\circ}\right)\end{array}$ \\
\hline $\begin{array}{c}\text { The Evaporative } \\
\text { Cooler with two } \\
\text { Bush Bearings }\end{array}$ & 23.07871 & 23.83033 \\
\hline
\end{tabular}

\begin{tabular}{|c|c|c|}
\hline $\begin{array}{c}\text { The Evaporative } \\
\text { Cooler with two } \\
\text { Cylindrical Roller } \\
\text { Bearings }\end{array}$ & 28.6729 & 31.164 \\
\hline
\end{tabular}

From table (4) it has been noted that the temperatures average of first and second cylindrical roller bearings were higher than the average of first and second bush bearings by $24.2396 \%$ and $30.7745 \%$ respectively. A reason of that was a less friction by using bush bearings than cylindrical roller bearings which lead to reduces resistance of the relativity motion between the contact surfaces.

\section{Noise Results and Discussions}

The sound level of the evaporative cooler has been measured experimentally with two bushings and with two cylindrical roller bearings respectively by using the Portable sound level meter, it has been found out that the sound level average by using 2 bushings in the evaporative cooler was $73.6 \mathrm{~dB}$ and it decreased bout $(0.9 \%)$ by using two cylindrical rollers bearing to be 72.9 $\mathrm{dB}$. A reason of that was the cylindrical geometric shape of rollers in cylindrical Roller Bearings facilitate smooth rolling of rollers between inner and outer race way.

\section{Conclusion}

Bearings are very important parts in the evaporative cooler due to its necessary function on the dynamic behavior of the rotating machinery. After the Comparison of the experimental results of vibration, bearings temperature, Sound level of the evaporative cooler with Bush and cylindrical roller bearings with no defects respectively it has been found:

1- The vibration of evaporative cooler by using two Cylindrical Roller Bearings in $\mathrm{X}, \mathrm{Y}$ and Z-directions increased by $229.6 \%, 220.4 \%$ and $226.6 \%$ respectively at the position of first accelerometer and $83.4056 \%, 81.6713 \%$ and $79.4949 \%$ respectively at the position of second accelerometer and $219.7812 \%, 241.1195 \%$ and $219.6703 \%$ respectively at the position of third accelerometer than using two Bush Bearings. A reason of increasing of vibration by using cylindrical roller bearing was the Existence of relatively large clearance compared with bushings clearance that causes impact among rollers, inner and outer races of cylindrical roller bearing.

2- The bearings temperatures remain volatile up and down in both cases but with more volatile at the bearing near the pulleys due to movement of rotary parts which works on cooling the bearings.

3- The temperatures average of first and second cylindrical roller bearings were higher than the average of first and second bush bearings by 
$24.2396 \%$ and $30.7745 \%$ respectively due to friction.

4- The noise of the evaporative cooler with using two of cylindrical roller bearings decreased by $(0.9 \%)$ than using two of bush bearings due to geometric shape of rollers.

5- It has been concluded that the evaporative cooler has better Performance by using bush bearings than using cylindrical roller bearings in it.

\section{References}

[1] SITRC, Mahiravani, Trimbak Road, Nashik, Maharashtra," A Study of Bearing and Its Types" International Journal of Advance Research in Science and Engineering. IJARSE, Vol. No.4, Special Issue (01), March 2015.

[2] Dr. S. J. Lacey, an overview on bearing vibration analysis, Nov/Dec 2008

[3] Eshleman, R. L.: "Basic Machinery Vibrations," VIPress, Clarendon Hills, Ill., 1999.

[4] K. Ragulskis and A. Yurkauskas, Vibration of Bearings, first edition, Hemisphere Publishing Corporation, 1989.
[5] T. A. Harris, Rolling Bearing Analysis, third edition, John Wiley \& Son, INC., 1991

[6] H. Ohta and N. Sugimoto, "Vibration Characteristics of Tapered Roller Bearings," Journal of Sound and vibration vol. 190, pp. 137-147, 1996.

[7] A. Palmgren, Ball and Roller Bearing Engineering, S. H., Burbank \& Co., Inc., 1959.

[8] M.S. Samhouri, A. A1-G handoor, R. H. Fouad, S. M. Alhaj Ali, "An intelligent opportunistic maintenance system: a genetic algorithm approach" JJMIE Vol 3, Number 4, pg. 246-251, December 2009.

[9] Harris T A, Rolling Bearing Analysis (4th Ed), Wiley, New York, 2001.

[10] Alaa A. Jaber and Robert Bicker, Real-Time Wavelet Analysis of a Vibration Signal Based on Arduino-UNO and Labview, Vol. 3, No. 1 March 2015.

[11] M. Gietzelt, K.-H. Wolf, M. Marschcllek and R. Haux,"Automatic self- calibration of body worn triaxial-accelerometers for application in healthcare," Pervasive Computing Technologies for HeaWcare, 2008. Pervasive Health 2008. Second international Conference on, pp. 177- 180, 2008.

\section{دراسة تأثير استخدام أنواع مختلفة من المحامل على اهتزاز جهاز التبريد بالتبخير}

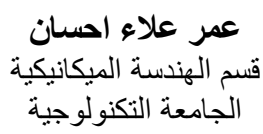

عمر علاء احسان

الجمامعة التكنولوجيكية الميكية

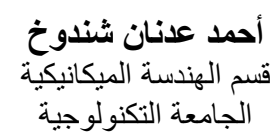

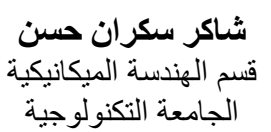

تم مناقثة الاداء لنوعين من أنواع المحامل هي المحمل الاسطو اني والمحمل من نوع بوش مستخدمة في في جهاز التهاز التبريد

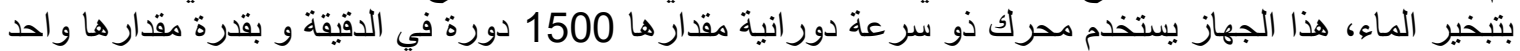

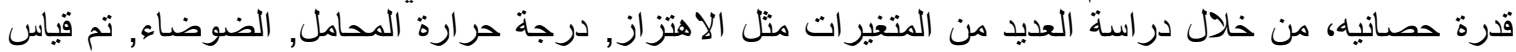

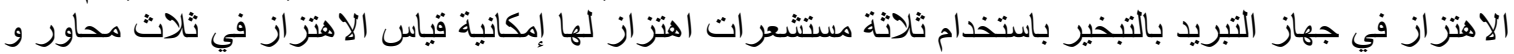

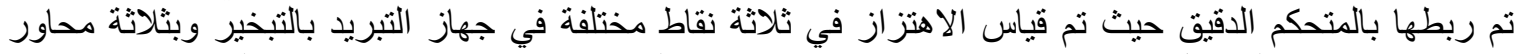

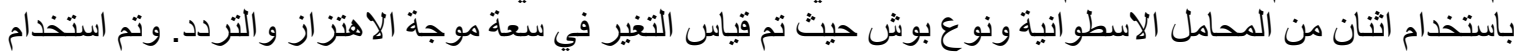

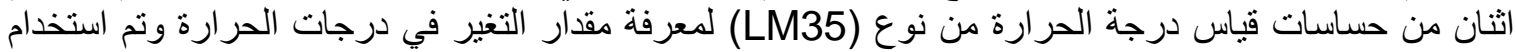

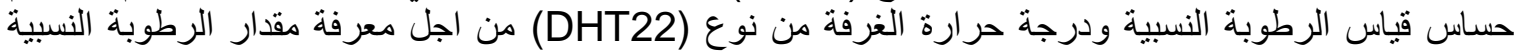

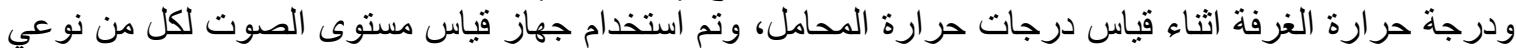

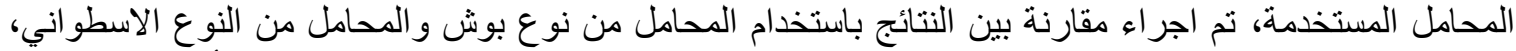

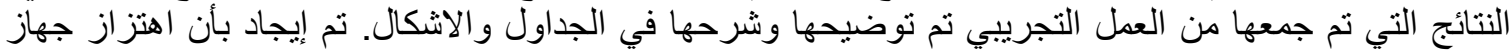

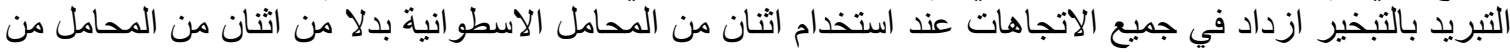

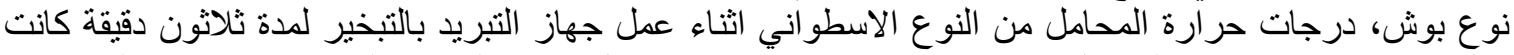

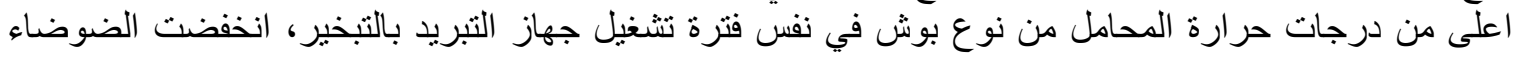

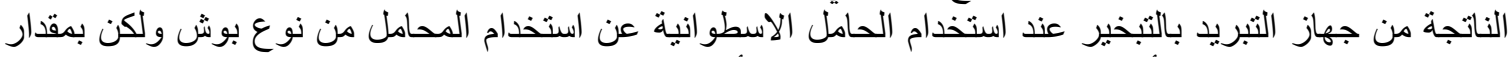

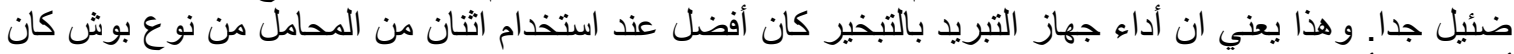

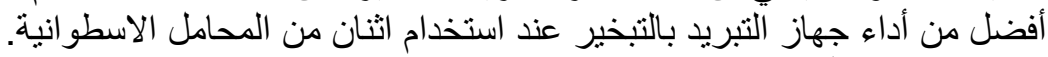

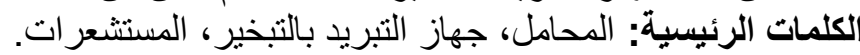

